JOURNAL OF SECURITY AND SUSTAINABILITY ISSUES

ISSN 2029-7017 print/ISSN 2029-7025 online

2019 December Volume 9 Number 2

http://doi.org/10.9770/jssi.2019.9.2(17)

Scopus

\title{
PREDICTING PLAUSIBLE THREATS: IMPACT OF GLOBALIZATION PATTERNS ON NATIONAL ECONOMIES
}

\author{
Alona I. Boiarchuk ${ }^{1 *}$, Vera N. Fomishyna ${ }^{2}$, Ruslan P. Ohorodnyk ${ }^{3}$ \\ ${ }^{1,2,3}$ External Economic Activity Department, Kherson National Technical University \\ 24 Beryslavsk highway, Kherson, 73008, Ukraine \\ E-mails: ${ }^{1 *}$ plal333@ukr.net (correspondingauthor)
}

Received 13 February 2019; accepted 18 October 2019; published 15 December 2019

\begin{abstract}
Relevance: With the increase of permeability of borders, in the conditions of active political interaction between regions, it became regular to witness appearance of many transnational companies (TNC) and metacorporations differing in forms of management and organizational connections. Where in the case of transnational companies we can most often observe trade expansion with the pushing out of the competitors working on the local market, the pattern more characteristic of metacorporations is merger and acquisition (MAA) where the management of the holding (as a rule) signs contracts with local manufacturers increasing their production capacity at the expense of local productions and businesses. The aim of this paper is to track the dynamics of international business development in the conditions of globalization and find out which regions and spheres of business are currently considered the most preferable for foreign investment. The results gained can be used in planning of perspective outlet markets and in search of new collaboration objects. The novelty of this paper lies in the observed character of interdependence of national economies and redistribution of investment flows between regions. The conclusions were made, that foreign investment flows (FIF) significantly influence the development of business inside the country: businesses with foreign capital receive a number of benefits compared to local companies.
\end{abstract}

Keywords: globalization; transnational companies (TNC); foreign investment flows (FIF); merger and acquisition (MAA); competition.

Reference to this paper should be made as follows: Boiarchuk, A. I., Fomishyna, V. N., Ohorodnyk, R. P. 2019. Influence of globalization processes on international business, Journal of Security and Sustainability Issues 9(2): 585-594.

http://doi.org/10.9770/jssi.2019.9.2(17)

JEL Classifications: F62, O19, G17.

\section{Introduction}

Integration processes of modern world economy contribute to development of globalization (Luk'yanenko, 2001; Zeibote et al., 2019; Masood et al. 2019; Kisel'áková et al., 2018; Koval et al, 2019). At the same time, we cannot look at processes of economy globalization and intensification of international business separately the degree of expressiveness of economic globalization in the region is directly proportional to the volumes of international trade and the amount of transnational companies represented in the region by their affiliates or manufacturing site.

By the term "economy globalization" we broadly mean rapid increase in commodity turnover, investment and credit flows, information, staff and ideas among certain countries, as well as increase in the geography of their influence. With the increase in speed of inter-penetration of such flows, national economies of the countries involved in this process gradually become inter-dependent. As a result of close economic interaction, many elements of national economic institutes integrate into common economic field and become one of components of global economy (Ad Fad, 1992) 
To track the development rate of economic globalization, we can compare the ratio between sales volumes and production volumes - over the last 50 years global trade growth dynamics considerably outruns global production growth rate. "Between 1950 and 2000 the world trade volume increased more than 20 -fold whereas inflation-adjusted world GDP increased only a bit more than 6-fold" (Iskrenko, 2003), or capital flows from one country to onother (Tvaronavičienè 2019).

For countries with developing market economy (according ratings of international organizations it's 35 countries including members of G7), integration into common economic space is one of main ways to avoid stagnation. This is connected primarily with the search for new outlet markets. In the context of international trade growth, economic globalization becomes inevitable (World Bank, 2013).

\section{Literature review}

The tendencies of international business development were first studied by A. Smith as far back as $2^{\text {nd }}$ half of the $17^{\text {th }}$ century. With the advent of the industrial revolution in England this issue became especially relevant. "If any foreign country can supply us with the product at a cheaper price than we ourselves are able to produce, it is much better to buy it from them for a certain amount of our own product which is applied in the sphere where we have certain advantage.” (Kislova, 2014).

Economic globalization had taken its final shape by the end of the $20^{\text {th }}$ century. By this time a number of multinational corporations had already appeared on the international market. Their example can be used to look at formation principles of transnational commercial corporations.

Many authors combine the terms "multinationalism" and "globalization" into one notion. However, in spite of a number of common features, these are different forms of business. Multinational corporations use ultimately different strategies of conducting a business for every country of presence, whereas global companies use only one business blueprint for all regional markets. (Jameson, 2000).

It is the activity of multinational corporations that contributed to the development of transnational economy in the form we can witness today. It turned into a sort of "world chess board" on which leading international companies compete (Movsesyan, 1997).

\section{Global transnational economy formation features}

Globalization of economy happens gradually, methodically involving in its field new countries and regions. We can witness global transnational economy formation in these features:

- Development of unified international scientific informational space and communication systems;

- Development of world financial market functioning on the basis of computer communication technologies;

- Increase in the interaction and interconnection of economies of separate countries and regions;

- Reorganization of commercial corporations for more efficient work in the format of international trade;

- Appearance of inter-state production corporations with placement of production sited in different countries;

- Increase in speed and volumes of international transactions: investments, credits, etc

- Merger of economies of separate countries and whole areas of industry with supernational corporations

- Appearance of many supernational structures of business control, formation of multilateral coordination contracts

- Cultural unification - global semination of unified cultural values and standards (partially smoothed out in the process of glocalization)

- Expansion of any economic factors at a global scale: shared crisis phenomena, shared prices and currency rates. 


\section{Goals}

Conducting international business gets complicated because of vide range of threats of various character (Joshi, 2009; Masood et al., 2019; Moumen et al., 2019; Rezk et al., 2019; Mikhaylov et al., 2018; Nikitina et al., 2018; Škuflić et al, 2018; Filipishyna et al., 2018; Kalyugina et al., 2018; Tvaronavičienè 2019; Abdullah et al, 2019, Cristiano Freitas Gomes et al., 2019; Olayinka A. Abiodun et al., 2019; Veli Sibiya., \& Tumo Kele 2019; Schwarz 2018; Energy Transformation towards Sustainability, 2019; Gagarina et al. 2019; Ohotina et al. 2018; Tvaronavičienè et al. 2018).

However, it is international business that serves as the primary stimulus for economic globalization. In this paper we will identify the most perspective areas of international business, identify regions and countries that enjoy the most popularity among foreign investors, and identify the most important factors that can influence the success of international business.

\section{Methodology}

We used these data sources:

- International reports on 2009-2017 world investments.

- Analytical summaries of Forbes, PwS, IMF

- Financial reports of large transnational companies available to public access

- Scientific reports of national and foreign scientists dedicate to economic globalization issues

- Statistics data, reports of rating agencies, news sources

Based on statistics data and reports, we can make a relevant prognosis of international business development for the next 1-2 years. As the basis for the research, we used search and selection of authentic information, analysis of factual data and description of objective dynamics of international market, data systemization and comparison of TNC distribution picture by regions.

\section{Results of the Study}

\section{Dynamics of international business development in the conditions of globalization}

Economic globalization benefits active business development. By limiting itself to internal market of only country the business needs to compete with representatives of their own country and import companies. This often leads to decrease in consumption value of products or services. At the same time, we should not exclude the possibility of price damping initiated by large international companies present on the local market.

Expansion to international level, in its turn, lowers the degree of competition. When tapping into new markets, a business can face absolutely empty or scarcely filled niches where its product would be much more in demand than in the country of production. In these conditions the producer can dictate the prices that are most beneficial for them and go on increasing their income. It will not be difficult for a large global company to drive out competition even from a fully formed market - competitors are eliminated by lowering prices, and the profit (avoid losses) is reached by means of regions with less competition. As a result, having eliminated the competition, the business can gradually set more profitable prices.

Theoretically, business can expand in any direction. However, in practice, company marketing experts take their time to design development strategies, since a potential outlet market is assessed by a number of criteria: GNP indexes, life standards as a whole, demographic situation, fund distribution structure (social stratification), political stability. To assess economic status of the country the World Bank often uses statistical reports where currency rate fluctuations within a period of 2-3 years are reflected, as well as inflation dynamics for the same period (Jameson, 2000). Choice in favor of a certain market is made based on the combination of factors. 
Given that, countries with a low but uniform GNP distribution among the population are always more attractive for TNCs than countries with high GNP and distinct social stratification.

Lowering production cost of the product is an additional advantage of globalization for large business. Having presence in several markets at once, the business increases production rates, gradually lowering expenses for each unit of product. A vivid illustration of this pattern is company Warner-Lambert, one of the largest world producers of pharmaceutical products. According to calculations of company analysts, the expenses for development and marketing of each new product are over $230 \mathrm{mln}$ dollars (UNCTAD, 2017). Keeping the product price consumers find attractive while fully covering expenses is only possible in the conditions of globalization, i.e. when the product is successfully sold on many markets.

In most cases global companies easily tap new markets. This is due to the company using proven marketing schemes in the new region. To promote products no special expense is necessary, while production volumes and profit increase proportional to volumes of new markets.

A good example is Coca-Cola Company, one of the largest world producers of soft drinks. The company first came to market in 1886, and it took the management 22 years to produce (and sell) their first billion bottles. Today, having transformed into a global company with representative offices in 195 countries, the company sells the same amount of product in 1 day! (Official website of Coca Cola, 2018).

Coca-Cola example can help us trace transformation of global marketing selling one and the same product. In the earlier days, companies used to develop a marketing project primarily for the internal market, and only afterwards would they adapt it to foreign markets. Today, marketing experts of transnational companies first develop universal solution for the global market and only afterwards make necessary corrections depending on the culture and traditions of each region separately (Ad Fad, 1992).

Alongside the economic globalization in the sphere of trade itself, we can witness pronounced processes of glocalization in the marketing sphere. The main task for marketing experts is to sell the product with minimum marketing expense. In such conditions creating one marketing product with further set of adaptations looks cost-efficient than creating a whole set of marketing projects.

One of the perfect examples of efficient marketing is Procter \& Gamble. (Official website of Procter \& Gamble, 2018). Procter $\&$ Gamble ranks $12^{\text {th }}$ in the list of the largest US companies. The company is the leader in their sphere on the world scale. It is the foreign operations (up to $53 \%$ of all sales) bring them maximum profit around $\$ 15.9$ billion per year.

\section{Case studies}

It is worth noting that the biggest percentage of large international company belongs to countries with developed market economy. Having developed a competitive product and tried out proven marketing schemes on the internal market, a corporation successfully expands its sphere of influence to neighboring regions. Russian business has not yet reached such level of development, so the tendency to globalization is only working on import on the local market so far.

Low globalization speed of Russian business is conditioned primarily by historical reasons. After the "iron curtain" fell and several re-organization waves came, local producers could not decide on their priorities for a long time and would make the products by outdated standards. The absence of competitive products and high production cost of local products is the main reason why Russian business does not yet have perspective in the foreign market. According to the information from the Global Competitiveness Report, as of beginning of 2017 Russia was ranked 43 $3^{\text {rd }}$ among 138 positions (Gerasimov|et al., 2018). Over the last several years there has emerged a trend to tighten quality control of local products, yet Russia risks playing exclusively the role of receiving party on the global market for quite some time with the existing level of production (Akhmetshin and Osadchy, 2015). 
Investments from the outside could level the situation and give Russian businesses a chance. And we are talking not only about financial investments, but also about technical re-equipment, new ideas and concepts. However, for foreign investors Russia is not very interesting. As a country with transitional economy, the Russian Federation has long been associated with high investment risks while investment conditions are strictly regulated on the state level. For example, one of early legislative drafts "National Security Policy of the Russian Federation (1996-2000)" suggested in 1996 by the office of the secretary of Security Council of the Russian Federation interpreted the possibility of "intensive buying-up of Russian businesses by foreign companies, especially at the lower price" (Politika natsional'noy..., 1996) as a threat. This draft was developed to protect of Russian businesses and lower the level of corruption, yet in reality it created a number of complications for foreign investments since real cost of stocks does not always correspond to the declared one.

As a result of a complex political and economic situation, globalization level in the Russian Federation remains in its infancy, and the country stays in the role of the receiving party on the world market (Table 1).

Table 1. Largest TNCs in the world by country

\begin{tabular}{|c|c|}
\hline Countries owning TNCs & Number of TNCs \\
\hline USA & 23 \\
\hline China & 11 \\
\hline France & 3 \\
\hline Japan & 5 \\
\hline United Kingdom & 1 \\
\hline Italy & 1 \\
\hline Germany & 3 \\
\hline Switzerland & 1 \\
\hline Netherlands & 1 \\
\hline Korea & 1 \\
\hline
\end{tabular}

Source: Global 500 2012.., 2017

In the list of 500 TNCs, Russia is represented by only three corporations whose activity is concentrated around the area of oil and gas extraction and processing. Let us recall that back in 2012 the rating Financial Times Global 500 (Global 500 2012..., 2017) listed 10 Russian companies. And even though their ratings were not that high, the trend to losing positions on the world market is easy to track. At the same time, the dynamics strongly varies even on the example of the last three years. Back in 2015 the leader of national TNCs, Gazprom, PJSC ranked 26, in 2016 - 56, and in 2017 - only 63.

\section{Principles of international companies' interaction}

Increase in the number of international companies leads to growth of competition between them. The largest corporations are forced not only to establish collaboration but also share outlet markets. Many world magnates are forced to initiate cooperation with competitor companies. (Can Honda..., 1999).

The result of close interaction between large international companies is entering into strategic alliances and international contracts. Transnational companies (TNC) can differ in form and contents. (Abramova, 2011). Quite often, they consolidate into complex metacorporations which are classified into holdings and non-holdings. (Keller, 1996).

Mechanisms of influence and management inside these corporations are regulated not only by the internal articles of incorporation but also by international investment treaties (IIT) which are entered into between leaders of governments. Considering the influence of foreign capital investments on local economy (Avdeeva, 2010, p.10), more and more countries try to change their investment policies which inevitably reflects on the format 
of interaction between TNC members (Gil'ferding, 2011; Akhmetshin et al., 2017).

Among the broad variety of collaboration forms, the most wide spread method is merger and acquisition (MaA). The biggest volume of purchases within MaA belongs to markets of developed countries - the USA, the United Kingdom and Australia. (Zagrebel'naya, 2015). Consolidation of business provides large companies with additional competitive advantages conditioned by increase in the scale of business and the possibility to use scientific and technical achievements of business partners.

The growth of MaA deals trending in 2005 is conditioned by the restoration of stock exchange after the preceding crisis. Total value of deals in 2005 amounted to almost $\$ 1$ bln, and a considerable part of mergers was international projects (Thomson Reuters, 2015). In the following years the activity of MaA deals saw an abrupt decline which was due to the influence of the world financial and economic crises. In 2010-2013, the situation gradually started to stabilize, and the total volume of deals (international and internal ones) amounted to $\$ 3 \mathrm{bln}$. (KPMG, 2014). We can observe further positive dynamics - the volume of MaA deals went on increasing on average by $30-40 \%$ yearly up to 2016 . When looking at the process of economic globalization, we can notice that the volume of MaA deals in the world is also rising (Table 2 and 3).

Table 2. Value of international MaA deals in 2010-2016 (bln USD) (UNCTAD, 2017)

\begin{tabular}{|c|c|c|c|c|c|c|c|c|c|c|c|c|c|c|}
\hline \multirow{2}{*}{ Region } & \multicolumn{7}{|c|}{ sale } & \multicolumn{7}{|c|}{ purchase } \\
\hline & 2010 & 2011 & 2012 & 2013 & 2014 & 2015 & 2016 & 2010 & 2011 & 2012 & 2013 & 2014 & 2015 & 2016 \\
\hline World & 347.094 & 553.442 & 328.224 & 262.517 & 428.126 & 735.126 & 868.647 & 347.094 & 553.442 & 328.224 & 262.517 & 428.126 & 735.126 & 868.647 \\
\hline $\begin{array}{c}\text { Countries } \\
\text { with } \\
\text { developed } \\
\text { economv }\end{array}$ & 259.926 & 436.926 & 266.773 & 230.122 & 293.062 & 640.762 & 794.317 & 224.759 & 431.899 & 183.858 & 120.683 & 244.077 & 587.455 & 707.528 \\
\hline $\begin{array}{l}\text { European } \\
\text { Union } \\
\text { countries }\end{array}$ & 118.187 & 184.582 & 128.270 & 126.585 & 174.874 & 265.255 & 362.593 & 23.108 & 142.022 & $1 \mathrm{~S} .99 \mathrm{~S}$ & -33.725 & 23.429 & 270.224 & 391.042 \\
\hline Germany & 10.515 & 13.440 & 7.793 & 17.457 & 17.378 & 14.593 & 6.357 & 7.025 & 5.644 & 15.674 & 6.674 & 38.639 & 47.640 & -8.126 \\
\hline $\begin{array}{l}\text { The United } \\
\text { Kingdom }\end{array}$ & 60.826 & 46.060 & 36.576 & 32.893 & 37.323 & 70.787 & 250.799 & -3.851 & 69.638 & -2.118 & -63.457 & -73.671 & 37.757 & 21.821 \\
\hline $\begin{array}{c}\text { Asian } \\
\text { countries }\end{array}$ & 37.723 & 55.967 & 33.360 & 47.829 & 97.269 & 49.919 & 41.861 & 79.865 & 80.499 & 92.819 & 108.511 & 139.927 & 122.609 & 143.235 \\
\hline China & 6.758 & 11.501 & 9.524 & 31.066 & 56.775 & 12.439 & 5.887 & 29.828 & 36.364 & 37.908 & 51.526 & 39.250 & 51.117 & 92.221 \\
\hline Japan & 7.114 & 4.671 & 1.791 & 4.423 & 6.159 & 3.065 & 20.088 & 31.271 & 62.263 & 37.795 & 58.275 & 45.889 & 50.623 & 80.646 \\
\hline The USA & 84.344 & 146.144 & 64.752 & 43.424 & 14.130 & 303.981 & 360.797 & 85.104 & 137.731 & 72.528 & 59.633 & 85.128 & 127.879 & 77.949 \\
\hline $\begin{array}{c}\text { Coun } \\
\text { tires with } \\
\text { transitional } \\
\text { economv }\end{array}$ & 4.095 & 32.966 & 6.825 & -54.845 & 5.708 & 10.000 & 5.014 & 5.378 & 13.108 & 9.296 & 3.074 & 4.636 & 4.501 & -0.809 \\
\hline $\begin{array}{c}\text { African } \\
\text { region }\end{array}$ & 7.493 & 8.634 & -1.254 & 3.8 IS & 5.442 & 21.259 & 9.689 & 3.792 & 4.393 & 0.629 & 3.212 & 5.485 & 3.533 & 6.061 \\
\hline $\begin{array}{l}\text { The Russian } \\
\text { Federation }\end{array}$ & 2.882 & 29.859 & 7.201 & -55.040 & 5.659 & 7.224 & 4.709 & 3.875 & 4.673 & 8.302 & 2.314 & 1.648 & 4.481 & 0.269 \\
\hline $\begin{array}{l}\text { Countries } \\
\text { with } \\
\text { developing } \\
\text { economy }\end{array}$ & 83.072 & 83.551 & 54.626 & 87.239 & 129.357 & 84.364 & 69.315 & 100.378 & 101.277 & 124.198 & 127.824 & 154.536 & 131.153 & 149.857 \\
\hline
\end{tabular}

Source: UNCTAD, 2017

Table 3. Dynamics of MaA in the world (bln USD and percents)

\begin{tabular}{|c|c|c|c|c|c|c|c|c|c|c|}
\hline Year & 2005 & 2006 & 2007 & 2008 & 2009 & 2010 & 2011 & 2012 & 2013 & 2014 \\
\hline & 33.7 & 33.6 & 44.8 & 38.3 & 27.1 & 37.5 & 35.3 & 35.3 & 30.5 & 36.9 \\
\hline bln USD & 900.3 & 1214.1 & 1849.4 & 1101.9 & 540.9 & 911.7 & 885.7 & 899.4 & 720.8 & 1285.9 \\
\hline
\end{tabular}




\section{Distribution of investment flows in the conditions of economic globalization}

Economy globalization also reflects on the level of foreign investment flows (FIF) into foreign countries. Based on the 2017-2018 results, FIF flows must have risen up to $\$ 1.8$ tln which is $5 \%$ more than the previous year, and in the current year they are expected to rise up to $\$ 1.85 \mathrm{tln}$. Main recipients of FIF in the future remain the United States, China and India.

Table 4. FDI flow in 20 largest receiving countries in 2017-2018.

\begin{tabular}{|c|c|c|c|c|}
\hline \multicolumn{5}{|c|}{ FDI inflows, top 20 host economies, 2017 and 2018 (Billions of dollars) } \\
\hline Country & Type of economy & 2017 Ranking & $\begin{array}{l}2018 \text { FDI inflow } \\
\text { (Billion of dollars) }\end{array}$ & $\begin{array}{l}2017 \text { FDI inflow } \\
\text { (Billion of dollars) }\end{array}$ \\
\hline United States & Developed & 1 & 252 & 277 \\
\hline China & Developing & 2 & 139 & 134 \\
\hline Hong Kong, China & Developing & 3 & 116 & 111 \\
\hline Singapore & Developing & 5 & 78 & 76 \\
\hline Netherlands & Developed & 7 & 70 & 58 \\
\hline United Kingdom & Developed & 4 & 64 & 101 \\
\hline Brazil & Developing & 6 & 61 & 68 \\
\hline Australia & Developed & 8 & 60 & 42 \\
\hline Spain & Developed & 17 & 44 & 21 \\
\hline India & Developing & 9 & 42 & 40 \\
\hline Canada & Developed & 15 & 40 & 25 \\
\hline France & Developed & 13 & 37 & 30 \\
\hline Mexico & Developing & 12 & 32 & 32 \\
\hline Germany & Developed & 11 & 26 & 37 \\
\hline Italy & Developed & 16 & 24 & 22 \\
\hline Indonesia & Developing & 18 & 22 & 21 \\
\hline Israel & Developed & 19 & 22 & 18 \\
\hline Vietnam & Developing & 21 & 16 & 14 \\
\hline Korea, Republic of & Developing & 20 & 14 & 18 \\
\hline Russian Federation & Developing & 14 & 13 & 26 \\
\hline
\end{tabular}

Source: UNCTAD, 2019

According to the opinion of managers of the largest world TNCs, the positive dynamics is expected in the Asian region in regards to which the growth of FIF is expected in the countries of South-East Asia: Indonesia, Thailand, the Philippines, Vietnam and Singapore.

\section{Conclusions}

Globalization processes open up perspectives for business, but requires careful planning. A certain number of difficulties can emerge only in receiving countries - foreign companies having experience and resources can eliminate local producers from the market which inevitably impacts the economy of the state. Economic activity of small local companies becomes economically unreasonable - they just can't compete as equals with transnational holdings. That is why expansion to international market will be beneficial only for producer countries. Foreign investment flows (FIF) significantly influence the development of business inside the country: businesses with foreign capital receive a number of benefits compared to local companies.

Additional financial investments stimulate industry growth forcing owners to look for new outlet markets that inevitably leads to issues of organizing export and strengthening international collaboration. For business representatives, expansion to foreign arena often seems to be the only appropriate way to keep and 
increase economic indices, since the demand for the product starts falling after the saturation of the local market, and in order to support former production rates (or intensify them), market expansion is necessary. This pattern is equally justified in both B2B sector and B2C sector. Main distinctions in the development of new trade connections consist in marketing strategies designed for large business owners or ordinary consumer respectively.

\section{References}

Abdullah, O., Khalizani, K., Fatima Mohsen, A. (2019). Exploring the role of safety culture factors towards safety behaviourin smallmedium enterprise. International Journal of Entrepreneurship, 23(3), 1-11.

Abramova, I. O. 2011. Developing countries in the global economy of the XXI century: formation of the new architecture of international economic relations. Eurasian International Scientific-Analytical Edition "Problems of Modern Economics" 1(37): 70-75. https://cyberleninka.ru/article/v/razvivayuschiesya-strany-v-mirovoy-ekonomike-hhi-veka-formirovanie-novoy-arhitektury-mezhdunarodnyh-ekonomicheskih-otnosheniy

Ad Fad. 1992. The Wall Street Journal, May 12, pp.17.

Akhmetshin, E. M. and Osadchy, E. A. (2015). New requirements to the control of the maintenance of accounting records of the company in the conditions of the economic insecurity. International Business Management 9(5): 895-902. http://docsdrive.com/pdfs/ medwelljournals/ibm/2015/895-902.pdf

Akhmetshin, E. M., Artemova, E. I., Vermennikova, L. V., Shichiyakh, R. A., Prodanova, N. A. and Kuchukova, N. M. (2017). Management of investment attractiveness of enterprises: Principles, methods, organization. International Journal of Applied Business and Economic Research 15(23): 71-82. https://shelly.kpfu.ru/e-ksu/docs/F_1234674847/SCOPUS._Management_of_investment_attractiveness_of_enterprises._2017.pdf

Avdeeva, A. V. (2010). Multinational Corporations in Contemporary World as a Factor of Globalization of the World Economy. New Technologies 1: 10-12. https://cyberleninka.ru/article/v/tnk-v-sovremennom-mire-kak-faktor-osuschestvleniya-globalizatsii-mirovoyekonomiki

Can Honda Go It Alone? (1999). Business Week 5.07.1999: 44. https://www.bloomberg.com/news/articles/1999-07-25/honda-can-thecompany-go-it-alone-cover-story-some-editions-july-5-intl-edition

Cristiano Freitas Gomes, Márcia De Mello Costa De Liberal, \& Chennyfer Dobbins Abi Rached. (2019). Cost management in a multiProfessional small-Scale clinic of popular health services. International Journal of Entrepreneurship, 23(2), 1-13.

Energy Transformation towards Sustainability. 1st Edition. Editors: Manuela Tvaronavičiene Beata Slusarczyk. ISBN: 9780128176887 Imprint: Elsevier Published Date: 1st November 2019. https://www.sciencedirect.com/book/9780128176887/energy-transformationtowards-sustainability

Filipishyna, L., Bessonova, S., Venckeviciute, G. (2018). Integral assessment of developmental stability: cases of Lithuania and Ukraine. Entrepreneurship and Sustainability Issues, 6(1), 87-99. http://doi.org/10.9770/jesi.2018.6.1(7)

Gagarina, G. Y., Sorokina, N. Y., Chainikova, L. N., Sizova, D. A., Nadyrov, S. M. (2019). Tools to ensure the economic security of the old industrial regions, Entrepreneurship and Sustainability Issues, 7(1), 747-762. https://doi.org/10.9770/jesi.2019.7.1(53)

Gerasimov, B.N., Vasyaycheva, V. A., Gerasimov, K.B. (2018). Identification of the factors of competitiveness of industrial "company based on the module approach, Entrepreneurship and Sustainability Issues 6(2): 677-691. https://doi.org/10.9770/jesi.2018.6.2(15)

Gil'ferding, R. (2011). Finansovyy kapital: novaya faza v razvitii kapitalizma [Financial Capital: A New Phase in the Development of Capitalism]. Moscow: Librokom Publ. ISBN: 978-5-397-02170-8

Global 500. 2012-2017. (2017). Financial Times. https://www.ft.com/ft500

Iskrenko, E. V. (2003). Mezhdunarodnyy biznes: Uchebno-metodicheskiy kompleks [International Business: Educational-methodical complex]. Volgograd: Publishing house of VolSU. http://economics.studio/biznes-mejdunarodniy/mejdunarodnyiy-biznes-uchebnometodicheskiy.html

Jameson, F. (2000). Globalization and political strategy. New Left Review 4 (July-August): 197-198. Retrieved from: https://newleftreview.org/II/4/fredric-jameson-globalization-and-political-strategy

Joshi, R. M. (2009). International Business. New Delhi and New York: Oxford University Press. ISBN-13: 978-0195689099 
Keller, T. (1996). Kontseptsii kholdinga: Organizatsionnyye struktury i upravleniye [Concepts of the holding: Organizational structures and management]. Translation from German. Obninsk: Higher Education and Science.

Kisel'áková, D., Šofranková, B., Čabinová, V., Onuferová, E. (2018). Competitiveness and sustainable growth analysis of the EU countries with the use of Global Indexes' methodology. Entrepreneurship and Sustainability Issues, 5(3), 581-599. http://doi.org/10.9770/ jesi.2018.5.3(13)

Kislova, L. A. (Ed.). (2014). Analiz dolgosrochnykh tendentsiy globalizatsii i ekonomicheskogo rosta [Analysis of long-term trends of globalization and economic growth], monograph.

Koval, V., Duginets, G., Plekhanova, O., Antonov, A., Petrova, M. (2019). On the supranational and national level of global value chain management. Entrepreneurship and Sustainability Issues, 6(4), 1922-1937. http://doi.org/10.9770/jesi.2019.6.4(27)

KPMG. (2014). Rynok sliyaniy i pogloshcheniy v Rossii v 2013 godu. [M \& A market in Russia in 2013]. Retrieved from: http://www. kpmg.com/RU/ru/IssuesAndInsights/ArticlesPublications/Documents/S_MA_3r_2014.pdf

Luk'yanenko, D. G. (Ed.). (2001). Strategiya ekonomicheskogo razvitiya v usloviyakh globalizatsii [Strategy of economic development in the conditions of globalization]. Monograph, Kyiv: KNEU.

Masood, O., Tvaronavičienė, M., Javaria, K. (2019). Impact of oil prices on stock return: evidence from G7 countries. Insights into Regional Development, 1(2), 129-137. https://doi.org/10.9770/ird.2019.1.2(4)

Mikhaylov, A.S., Mikhaylova A.A., Savchina, O.V. (2018). Innovation security of cross-border innovative milieus, Entrepreneurship and Sustainability Issues 6(2): 754-766. http://doi.org/10.9770/jesi.2018.6.2(19)

Moumen, Z., El Idrissi, N.E.A., Tvaronavičienè, M., Lahrach, A. (2019). Water security and sustainable development. Insights into Regional Development, 1(4), 301-317. https://doi.org/10.9770/ird.2019.1.4(2)

Movsesyan, A. G. (1997). Integratsiya bankovskogo i promyshlennogo kapitala: sovremennyye mirovyye tendentsii i problemy razvitiya $v$ Rossii [Integration of banking and industrial capital: modern world trends and development problems in Russia]. Moscow: Finance and Statistics.

Nikitina, M.G., Pobirchenko, V.V., Shutaieva, E.A., Karlova, A.I. (2018). The investment component in a nation's economic security: the case of the Russian Federation, Entrepreneurship and Sustainability Issues 6(2): 958-967. http://doi.org/10.9770/jesi.2018.6.2(32)

Official website of Coca Cola. (2018). Retrieved from: https://www.coca-colacompany.com/ (Accessed on 6.02.2018)

Official website of Procter \& Gamble. 2018. Retrieved from: https://us.pg.com (Accessed on 3.03.2018)

Ohotina, A., Lavrinenko, O., Gladevich, J., Lazdans, D. (2018). The investment climate in Latvia's, Lithuania's and Belarus's crossborder regions: the subjective-objective assessment. Entrepreneurship and Sustainability Issues, 6(2), 767-780. http://doi.org/10.9770/ jesi.2018.6.2(20)

Olayinka A. Abiodun, Emmanuel K.Agbaeze, Bamidele S.Adeleke, Nwanneka C. Ghasi., \& Anthony O.Ude. (2019). Do leadership roles affect survivability of family businesses in developing economies? . International Journal of Entrepreneurship, 23(2), 1-10.

Politika natsional'noy bezopasnosti Rossiyskoy Federatsii (1996-2000) (proyekt) 1996. [The National Security Policy of the Russian Federation (1996-2000) (draft)]. Nezavisimaya gazeta-Stsenarii, 2.

Rezk, M.R., Radwan, A., Salem, N.M., Sakr, T.M., Tvaronavičienė, M. (2019). Foresight for sustainable energy policy in Egypt: results from a Delphi survey. Insights into Regional Development, 1(4), 357-369. https://doi.org/10.9770/ird.2019.1.4(6)

Schwarz, D. (2018). The ability of listed companies to optimize their capital structure, shape their distribution policy and fight hostile takeovers by repurchasing their own shares, Entrepreneurship and Sustainability Issues 6(2): 636-648. https://doi.org/10.9770/ jesi.2018.6.2(12)

Škuflić, L., Krpan, M., Žmuk, B. (2018). Migration and the economic crisis in the European Union member states: cluster analysis, Entrepreneurship and Sustainability Issues 6(2): 979-1000. https://doi.org/10.9770/jesi.2018.6.2(34)

Thomson Reuters. 2015. Preliminary Mergers \& Acquisitions Review. http://share.thomsonreuters.com/general/PR/MA-4Q15-(E).pdf

Tvaronavičienè, M. (2019). Insights into global trends of capital flows' peculiarities: emerging leadership of China. Administratie si Management Public, (32), 6-17. https://doi.org/10.24818/amp/2019.32-01

Tvaronavičienè, M. (2019). Insights into global trends of capital flows’ peculiarities: emerging leadership of China. Administratie si 
Management Public, (32): 6-17, https://doi.org/10.24818/amp/2019.32-01

Tvaronavičienė, M., Masood, O., Javaria, K. (2018). Preconditions of the Eurozone economic security: how to overcome liquidity risk and cost inefficiency in leading banks of UK and Germany, Polish journal of management studies, 18(1), 418-427. https://doi. org/10.17512/pjms.2018.18.1.31

UNCTAD (United Nations Conference on Trade and Development). (2017). World Investment Report 2017. Investment and Digital Economy, pp. 25. Retrieved from: http://unctad.org/en/PublicationsLibrary/wir2017_en.pdf

UNSTAD. 2019. World Investment Report 2019. Special economic zones. ISBN 978-92-1-112949-6. Retrieved from: https://unctad.org/ en/PublicationsLibrary/wir2019_en.pdf

Veli Sibiya., \& Tumo Kele. (2019). Barriers and Public Policies Impeding Smes' International Market Expansion: A South African Perspective. International Journal of Entrepreneurship, 23(1), 1-19.

World Bank. 2013. Global economic prospects: Assuring Growth Over the medium Term, 6, January: 41. https://doi.org/10.1596/9780-8213-9882-1

Zagrebel'naya, N. S. (2015) World and Russian market of mergers and acquisitions. Bulletin of Moscow State Institute of International Relations (University) of the Ministry of Foreign Affairs of Russia. World economy 2(41): 163-170. http://webcache.googleusercontent. com/search?q=cache:http://www.vestnik.mgimo.ru/sites/default/files/pdf/017_ekonomika_zagrebalnayans.pdf

Zeibote, Z., Volkova, T., Todorov, K. (2019). The impact of globalization on regional development and competitiveness: cases of selected regions. Insights into Regional Development, 1(1), 33-47. https://doi.org/10.9770/ird.2019.1.1(3)

Alona Igorevna BOIARCHUK is a $\mathrm{PhD}$ in Economics, Associate Professor at the External Economic Activity Department of Kherson National Technical University in Ukraine.

ORCID ID: orcid.org/0000-0003-3680-162X

Vera Nikolaevna FOMISHYNA is a PhD in Economics, Professor at the External Economic Activity Department of Kherson National Technical University in Ukraine.

ORCID ID: orcid.org/0000-0002-7276-3280

Ruslan Petrovich OHORODNYK is an Assistant Professor at the External Economic Activity Department of Kherson National Technical University in Ukraine.

ORCID ID: orcid.org/0000-0001-5038-9198

This work is licensed under the Creative Commons Attribution International License (CC BY).

http://creativecommons.org/licenses/by/4.0/ 